\title{
HISTORIOGRAFI ISLAM: Bio-biografi dan Perkembangan Mazhab Fikih dan Tasawuf
}

\author{
Ajid Thohir \\ Fakultas Adab dan Humaniora UIN Sunan Gunung Djati Bandung \\ Jl. Raya Cipadung No. 105, Cibiru, Bandung, 10614 \\ e-mail: ajid_thohir@yahoo.com
}

\begin{abstract}
Abstrak: Studi bio-biografi dalam historiografi Islam, menempati posisi strategis terutama dalam penguatan dan pembentukan mazhab-mazhab di dunia Islam, khususnya dalam bidang fikih dan tasawuf. Tulisan ini mencoba menelusuri dan memetakan bagaimana arah dan model perkembangan studi bio-biografi dalam historiografi Islam. Penulis mengemukakan bahwa hubungan antara sebuah karya dengan dinamika kultural pada setiap ruang dan waktu, mencerminkan masingmasing karya sejarah semakin sarat dengan muatan kepentingan kultural yang sangat kompleks. Kajian bio-biografi tidak hanya terbatas pada bentuk sîrah, thabaqât, tarjamah, ansâb, namun yang paling fenomenal adalah munculnya hagiografi (manâqib), sebuah kajian yang menempatkan seseorang sebagai tokoh puncak intelektual dan spiritual. Kitab manâqib merupakan simbol dalam ikatan mazhab membentuk kohesivitas psikologis bagi para pengikut mazhabnya.
\end{abstract}

\begin{abstract}
Islamic Historiography; the Bio-biography and the Development of schools of Fiqh and Tasawuf. The study of bio-biography in Islamic historiography occupies a strategic position, particularly in strengthening and establishing the schools in the Islamic world especially in the realm of fiqh and tashawuf. This paper traces and attempts to map the direction and development of bio-biographical studies in Islamic historiography. The author argues that the relationship between a work and the cultural dynamics at any given time and space, reflecting their respective historical work that highly motivated by the complex cultural interest. The study of bio-biography is not only confined to such works as thabaqât, tarjamah, and ansâb, but it may also be in the form of manâqib, that let someone enjoy the position as the most important intellectual and spiritual figure. The manâqib also symbolizes the schools bond that forms a psychological cohesiveness to the disciples of respective mazhab.
\end{abstract}

Kata Kunci: bio-biografi, historiografi, ketokohan, fikih, tasawuf 


\section{Pendahuluan}

Perkembangan historiografi Islam, menunjukkan dinamika yang sangat kompleks dan dinamis. Kenyataan ini telah dibuktikan oleh munculnya sejumlah karya sejarah Islam dengan berbagai jenis variasi, model, tipe, wujud, bentuk dan karakter isinya. ${ }^{1}$ Realitas keragaman ini didorong oleh adanya berbagai motif dan latarbelakang sosio kultural dan struktur ideologi tertentu yang memengaruhi para penulis sejarah. Momentum kemunculannya bisa saja akibat kondisi dan situasi tertentu serta isu-isu yang mendominasi dan memainkannya, atau oleh kualitas intelektualitas sejarawan sendiri saat melakukan proses perwujudannya. ${ }^{2}$

Studi ketokohan pada berbagai karya sejarah Islam (historiografi Islam), merupakan salah satu cara yang cukup efektif untuk mengukur kreativitas dan kesadaran kultural masyarakat dalam memahami dan mengapresiasi kehidupan ketokohan keagamaan (mazhab) pada masa lalunya. Melihat berbagai model tulisan tentang sejarah tokoh dan mengklasifikasi bagaimana bentuk, corak, struktur isi dan keunikannya adalah sesuatu yang sangat memungkinkan untuk mengerti dan memahami sejauh mana sebuah kecenderungan dan keberadaan intelektualitas seseorang mengisi dan mewarnai corakcorak komunalitas keagamaannya. Perkembangan tulisan keagamaan baik berupa teks doktrin (kalam, fikih dan tasawuf) maupun studi ketokohannya, setidaknya dapat mewakili dan memposisikan diri dalam pengembangan historiografi Islam secara umum, dan memiliki korelasi yang sangat kuat terhadap realitas pembentukan komunalitas berbagai mazhab. ${ }^{3}$ Mengkaji secara akademik tentang model-model studi ketokohan dalam historiografi Islam merupakan salah satu upaya untuk mengetahui realitas yang sesungguhnya bagaimana arti, posisi, signifikansi dan keberadaan seorang tokoh dalam sejarah, serta memahami seberapa besar nilai dan apresiasi sejarawan terhadap studi ketokohan dalam dunia Islam. Berikut ini adalah tulisan yang ingin mencoba memetakan bagaimana arah dan model perkembangan studi ketokohan dalam historiografi Islam.

${ }^{1}$ Wustenfeld, sarjana Jerman yang ahli di bidang pernaskahan sejarah, telah melakukan identifikasi dan pengumpulan sejak tahun $1882 \mathrm{M}$. tentang banyaknya naskah-naskah sejarah di dunia Islam. Pada Millenium Pertama saja telah muncul tidak kurang dari 590 jenis karya, semua naskah sejarah tersebut telah memiliki berbagai tipe berikut dengan karakter perbedaannya. Naskah-nakah sejarah tersebut terbagi ke dalam berbagai area, dari mulai Persia dan Turki sebagaimana yang telah disurvey oleh C. A. Storey (1935) dan F. Babinger (1927), juga sampai ke wilayah paling Barat warisan dunia Islam di Spanyol sebagaimana hal yang sama yang dikumpulkan oleh F. Pons Boigues pada tahun 1889. Penelitian yang dilakukan sejak tahun 1898-1902 oleh C. Brockelmann secara keseluruhan pada akhirnya dibukukan dalam karyanya Geschicte der Arabischen Litteratur (GAL) Franz Rosenthal, A History of Muslim Historiography (Leiden: E. J. Brill, 1968), h. 3-4.

${ }^{2}$ W. H. Walsh, Philosophy of History: An Introduction (New York: Harper Torchbooks, 1967), h. $99-116$.

${ }^{3}$ Sayyid 'Abd al-Azîz Sâlim, Al-Târikh wa al-Mu'arrikhûn (Beirut: Dâr al-Nahdhah al-Arabiyyah, t.t.), h. 75-96. 
Ajid Thohir: Bio-biografi dan Perkembangan Mazhab Fikih dan Tasawuf

\section{Posisi dan Fungsi Historiografi Islam}

Dari segi bahasa, kata "historiografi" mengandung arti penulisan sejarah, ${ }^{4}$ tulisan sejarah, ${ }^{5}$ dan mengandung arti tentang sejumlah literatur yang berkait dengan ilmu sejarah. ${ }^{6}$ Dalam pengertian yang lebih populer atau tinjauan kekinian, para ahli sejarah mengenalkan pengertian historiografi lebih cenderung untuk mengarah pada dimensi keilmuan yang memberikan gambaran tentang berbagai model karya sejarah. Nisar Ahmed Faruqi ${ }^{7}$ mendefinisikan secara khusus, "historiography is the science of committing anecdotes and their causes to writing with reference to the time of their occurance".

Secara terminologis Rosenthal juga menyebutkan bahwa historiografi Islam adalah karya sejarah yang ditulis oleh penganut agama Islam dari berbagai alirannya. ${ }^{8}$ Sedangkan HAR. Gibb menyamakan pengertian historiografi Islam dengan ilmu al-tarîkh, yang dalam literatur Arab mencakup bentuk analytic (kronologis) maupun biografis. ${ }^{9}$ Historiografi Islam adalah studi yang menyangkut dengan berbagai ilmu sejarah dan karya sejarah dalam kaitannya dengan hal-hal yang menyangkut berbagai hasil tulisan yang diciptakan oleh kaum Muslim dalam menggambarkan aktivitas manusia dalam setiap ruang dan waktunya.

Historiografi sebagai bagian dari ilmu sejarah modern, menjadi sesuatu yang sangat penting untuk diposisikan secara akademis karena status keilmuannya yang begitu besar dalam memberi kewenangan untuk melihat, membandingkan bahkan menilai berbagai karya penulisan sejarah. Posisi studi ke arah ini menjadi semakin penting ketika ia dihubungakan dengan perkembangan mental dan intelektualitas kaum Muslim dalam memahami dan menyikapi serta membangun kesadaran masa lalunya. Berbagai karya tulisan sejarah merupakan satu-satunya wujud dari semua bentuk ekspresi dari kesadaran terhadap masa lalu. Apalagi bila mengingat bentuk penulisan sejarah adalah puncak dari totalitas keilmuan setiap sejarawan, ${ }^{10}$ yang di dalamnya merangkum semua gagasan, proses, metodologi, tema, semangat, ideologi dan sebagainya yang menjadi pilihan dari seluruh kemampuan dan tanggungjawabnya sebagai ilmuan. Sebab apa yang dituliskan sejarawan merupakan refleksi dari kemampuannya dalam menangkap dan memahami

${ }^{4}$ William Morris, et al. (ed.), The Heritage Illustrated Dictionary of the English Language, Vol. I (Boston: Houghton Mifflin Company, 1979), h. 625.

${ }^{5}$ James A. H. Murray, et al., (ed.), The Oxford English Dictionary (Oxford: The Clarendon Press, 1978, h. 305.

${ }^{6}$ Morris, et al. (ed), The Heritage Illustrated Dictionary, h. 625.

${ }^{7}$ Nisar Ahmed Faruqi, Early Muslim Historiography (Delhi: Idarah-i Adabite Delli, 1979), h. 2 .

${ }^{8}$ Rosenthal, "Islamic Historiography," dalam David L. Sills (ed.), International Encyclopedia of Social Sciences, Vol. V (New York: The Macmillan Company \& The Free Press, 1972), h. 407.

${ }^{9}$ Hamilton A.R. Gibb, Studies on The Civilization of Islam (Boston, Beacon Press, 1968), h. 108.

${ }^{10}$ Taufik Abdullah, "Sejarah dan Historiografi," dalam Ilmu Sejarah dan Historiografi: Arah dan Perspektif (Jakarta: Gramedia, 1985), h. xv. 
berbagai peristiwa sejarah yang betul-betul pernah terjadi (histoire-realite), baik pada diri individu maupun sosial kolektif.

Manfaat dari kajian historiografi akan mempermudah dalam menyoroti isi filosofis dan teoritis dari penelitian dan karakter setiap penulisan sejarah, termasuk pandangan hidup (weltanschauung) dari setiap sejarawannya. Karena historiografi memiliki karakter yang berbeda-beda menurut negerinya, masanya, kepribadiannya serta komunitasnya. ${ }^{11}$ Mempelajari historiografi tidak terlalu banyak menuntut aspek-aspek substantif-faktual dari proses sejarah, tapi lebih mengutamakan dan memusatkan perhatiannya terhadap pikiran-pikiran historis dalam konteks kultural penulisannya, sehingga hasilnya diharapkan akan mempertinggi kemampuan penstudi dalam membuat pandangan (self-reviewing) dan perbaikan (self-correcting) serta menaruh perhatian pada setiap karya yang dikajinya. ${ }^{12}$

Dalam tradisi keilmuan Islam, ilmu sejarah (al-târikh) telah dikategorikan secara khusus sebagai bagian dari ilmu-ilmu keagamaan (ulûm al-dîniyyah atau ulûm alnaqliyyah) karena pada awal pertumbuhannya terkait erat dengan perkembangan ilmu hadis. ${ }^{13}$ Sebelum munculnya kesadaran akan pentingnya hadis sebagai salah satu sumber dari ajaran Islam, kaum Muslim belum begitu mempedulikan arti penting dan manfaat pendokumentasian dan catatan tentang perilaku keseharian Nabi Muhammad SAW. dalam mempraktekkan nilai-nilai kewahyuan di tengah-tengah umatnya. Seluruh informasi tentang masa lalu hanya cukup diceritakan para rawi atau didengarkan saja pada mereka yang kebetulan membutuhkan penjelasan atau kebetulan menanyakan mengenai bagaimana Nabi Muhammad SAW. melakukan atau memutuskan sesuatu masalah.

Selanjutnya, meskipun pada mulanya praktik mengumpulkan hadis-hadis Nabi Muhammad SAW. karena untuk kepentingan dan keperluan kegiatan agama, saat meriwayatkan segala tindakan dan perbuatan Nabi Muhammad SAW. atau yang biasa disebut takhrij hadis atau atsar sebagai dasar hukum Islam, maka dengan serta merta kegiatan ini bagi para ulama bisa dijadikan sebagai praktek dalam melakukan kajian sejarah secara kritis. Seluruh informasi hadis tentang perbuatan Nabi Muhammad SAW., para sahabat yang berpartisipasi di dalamnya, bagi para tabiin atau tabit-tabiin dan seterusnya yang ingin mengetahui dan kelak akan mengikutinya, adalah realitas sosio kultural keagamaan dan bentuk kesadaran sejarah yang luar biasa hebatnya. Karena mereka meyakini bahwa hadis-hadis Nabi Muhammad SAW. merupakan nilai kewahyuan kedua yang saat itu masih berserakan dan berada di mana-mana seiring para sahabat dan tabiin yang banyak migrasi ke berbagai wilayah di luar Makkah dan Madinah, yang tentunya keseluruhannya harus dikumpulkan secara selektif. Inilah zaman yang

${ }^{11}$ Raymond Aron, Introduction to the Philosophy of History (New York: Doubleday Anchor, 1961), h. 282.

${ }^{12}$ Sartono Kartodirdjo, Pemikiran dan Perkembangan Historiografi Indonesia: Suatu Alternatif (Jakarta: Gramedia, 1982), h. 14-15.

${ }^{13} Y u s r i$ 'Abd al-Ganî, Mu'jam al-Muarrikhîn al-Muslimîn (Kairo: Dâr al-Turats, 1998), h. 1. 


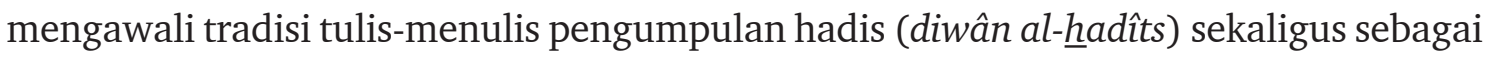
sebuah kesadaran sejarah. Karena semua kumpulan informasi masa lalu yang terjadi pada diri Nabi Muhammad SAW. dan para sahabatnya tersebut, kelak akan dijadikan sebagai dasar dan pijakan bagi praktek keagamaan oleh mereka dan generasi berikutnya secara menyeluruh.

Dari seluruh kegiatan ilmiah tersebut, pada akhirnya para ulama abad ke-4 H ini dapat menemukan dan merumuskan secara metodologis aspek-aspek penting yang bisa mendeteksi tentang berbagai informasi dan fakta-fakta sejarah (al-khabar) yang bisa dipertanggungjawabkan kebenaran atau kesahihannya. Secara realistik, penemuan tentang metode yang bisa menjamin kualitas tentang informasi atau khabar tersebut kemudian disebut ulûm al-hadîts yang meliputi 'ilm al-rijâl, 'ilm al-matan, 'ilm al-jarh wa al-ta'dîl, dan al-thabaqât. ${ }^{14}$ Dengan demikian, munculnya ilmu sejarah (al-târikh) di dunia Islam secara umum bisa dipastikan dan didasari oleh adanya perkembangan ilmu hadis. ${ }^{15}$

Perkembangan ilmu sejarah (al-târikh) sebagai disiplin ilmu pada periode ini pada satu sisi belum bisa dinyatakan secara khusus terpisah sebagaimana tafsir, hadis, fikih dan kalam. Tetapi produktivitas karya dan penggunaannya sangat terasa sebagai ilmu bantu, dan begitu penting dalam membantu menemukan pemahaman keislaman. Karena itu, posisi ilmu târikh pada periode awal masih identik dengan prosa atau sya'ir yang bisa menjelaskan aspek-aspek tertentu dari permasalahan keagamaan maupun persoalan-persoalan hukum secara khusus, dan ia merupakan ilmu yang sangat banyak faidah dan manfaatnya. ${ }^{16}$ Periode transmisi ilmu-ilmu Yunani ke dunia Islam, nampaknya tidak memberi dampak sama sekali bagi pengembangan model-model studi sejarah di kalangan para sarjana Muslim saat itu, sehingga bisa dikatakan sejarah merupakan bentuk ilmu pengetahuan asli dunia Islam atas dorongan ilmu hadis dan tafsir al-Qur'an serta

${ }^{14}$ Aspek-aspek dari ulûm al-hadîts yang begitu banyak itu, nampaknya sebagai upaya serius dari para ulama periode Klasik dalam menelusuri dan mencari berbagai informasi kewahyuan yang disandarkan dari sabda-sabda Nabi Muhammad SAW. Informasi tersebut berserakan di antara para sahabat, kemudian turun pada para tabiin dan tabiit-tabiin dan seterusnya yang selanjutnya disebut sebagai râwi (periwayat), sehingga validitas, kredibilitas serta objektifitas tentang informasi materi (matan hadis) yang disampaikan oleh sumber atau para perawi hadis tersebut sangat diutamakan. 'Ilm rijâl adalah ilmu yang menyelidiki tentang kredibilitas seorang perawi hadis. 'Ilm matan adalah ilmu yang menyelidiki secara khusus isi informasi, mutu dan kualitas serta maknanya apakah selaras dengan nilai-nilai kewahyuan atau syariat yang ada atau tidak, termasuk dari segi-segi bahasa yang disandarkan pada gaya bahasa Nabi Muhammad SAW. 'Ilm Jarh wa Ta'dîl, adalah yang mengkritisi secara detil orang-orang yang akan dijadikan perawi hadis, termasuk kelompok orang-orang yang dianggap diragukan sebagai ahli hadis, orang-orang pelupa, ragu-ragu, lemah hapalan, suka berdusta atau mengarang cerita. Thâbaqât adalah ilmu yang menyelidiki tingkatan dan status seseorang dalam kategori zaman, karakter atau profesi dan sebagainya. Relasi ilmu sejarah dan hadis telah dipaparkan oleh al-Sakhawî (w. 1494 M) dalam karyanya I lân bi al-Taubîkh li man Dzamma Ahl al-Tawârikh.

${ }^{15}$ Faruqi, Early Muslim Historiography, h. 185-186.

${ }^{16}$ Al-Muhy al-Kâfiyaji, "Al-Mukhtashar fî 'Ilm al-Târikh," dalam 'Izz al-Dîn 'Alî, Dirâsât alNaqdiyyat fì al-Mashâdir al-Târikiyyat (Beirut: 'Alam al-Kutub, t.t.), h. 15-16. 
warisan klasik Arab. Karena para ahli sejarah Islam sepakat bahwa istilah 'ilm al-târikh atau historiografi Islam, betul-betul berangkat dan berakar dari tradisi khabar yang biasa berkembang di kalangan masyarakat Arab sebelum Islam, atau yang biasa dikenal ayyâm $a l-A r a b$, yakni cerita peristiwa (peperangan) suku-suku mereka. ${ }^{17}$ Namun pada perkembangan berikutnya sejarah mendapat perhatian khusus dalam disiplin ilmu-ilmu keislaman, baik untuk kepentingan karena berkait dengan ilmu-ilmu tertentu seperti $a s b a ̂ b$ al-nuzûl bagi studi teks-teks al-Qur'an maupun asbâb al-wurûd bagi studi teks-teks hadis Nabi Muhammad SAW. berikutnya. ${ }^{18}$

Dengan demikian, ada dua faktor penting yang mendukung bagi berkembangnya penulisan sejarah di dunia Islam atau sesuatu yang melatarbelakangi gerakan tumbuhannya historiografi Islam saat itu, yakni pertama akibat dorongan al-Qur'an yang menekankan penting belajar sejarah, termasuk al-Qur'an secara langsung telah mencontohkan berbagai penulisannya dan memberikan informasi tentang sejarah masa lalu umat manusia berikut tokoh-tokoh yang ada di dalamnya. Kedua, karena ditunjang oleh lahirnya ilmu hadis. Motivasi untuk mengenal dan mengetahui secara detil pola dan perilaku Nabi Muhammad SAW. bersama sahabat-sahabatnya dalam mengaplikasikan ajaran al-Qur'an, secara tidak langsung mendorong para ulama keagamaan untuk terlibat langsung dalam kajian sejarah yang kritis. Dengan bekal lmu hadis pula mereka menjadikan metode kritik penulisan sejarah paling awal, karena aspek-aspek metodologis di dalamnya sangat jelas dan lugas dalam menentukan objektivitas berbagai informasi masa lalu.

\section{Historiografi Islam: Sejarah Tokoh dan Sejarah Sosial}

Bagi sebagian sejarawan Muslim, menuliskan berita tentang masa lampau seperti dijelaskan di atas, bukan hanya atas dasar tuntutan sosial keagamaan, tapi juga secara doktrinal teks al-Qur'an sendiri banyak memberi pengaruh yang cukup kuat. Bahkan teks suci mereka sendiri, al-Qur'an memberi contoh penulisan yang sangat realistik dalam menceritakan tentang banyak hal mengenai realitas kehidupan individual dan sosial

\footnotetext{
${ }^{17}$ Hussain Nashshar, Nasy'at al-Tadwîn al-Târikhy 'inda al-Arab (Kairo: Maktabah alMishriyah, t.t.), h. 6-7.

${ }^{18}$ Menurut Hussain Nashshar tradisi penulisan sejarah Islam awal berkembang dari dua arus. Pertama arus lama yakni kelanjutan dari cerita-cerita khayal dan folklore arab yang disampaikan oleh narator-narator yang berpindah-pindah dari Arab Utara dalam bentuk alansâb dan al-ayyâm, dan cerita tentang raja-raja Arab Selatan serta riwayat penaklukan mereka. Biasanya arus lama ini berbentuk syair. Kisah-kisah mereka tidak didasarkan pada penanggalan kejadian, dan antar peristiwa tidak menggambarkan hubungan. Kedua, arus baru, yakni gerakan penulisan sejarah yang dimunculkan oleh Islam yang didasarkan atas berita-berita yang otentik dan mendalam berbentuk sîrah atau biografi yang didasarkan pada tradisi penulisan hadis. Informasi yang dikandungnya didapat dari hasil seleksi dan kritik. Meskipun demikian kenyataannya ada juga yang berupa khayalan tentang diri rasul, akibat pengagungan kaum Muslim pada rasulnya. Para sejarawan mengumpulkan semua kisah tersebut dan menggabungkannya serta menjelaskannya dengan beberapa ayat al-Qur’an. Nashshar, Nasy'at al-Tadwîn al-Târikhî, h. 67-68.
} 
pada masa lampau. Sejumlah surat dan ayat menceritakan peran dan perilaku mereka dan sejumlah aspek yang menyangkut pola dan tradisi kehidupannya. Semunya digambarkan secara konkrit dan realistik dalam al-Qur'an, baik menyangkut peran dan perilaku yang disenangi maupun yang dinilai sangat jelek atau kontoversial secara moral. Pola pengungkapan al-Qur'an terhadap semua peristiwa yang terdapat dalam kandungan al-Qur'an, direkam dan dijelaskan oleh ratusan ayat ada yang dituliskan secara global ada juga sampai pada hal-hal yang sangat detilnya, semacam dialog dan ungkapan hati. Seperti halnya kisah para Nabi, keluhan dan perasaan Nabi Zakaria as. yang menghendaki generasi keturunan, dialog Musa as. dengan Fir'aun, dan kisah perjalanan Nabi Yusuf as. dan keluarganya, dijelaskan cukup jelas dalam al-Qur'an. ${ }^{19}$

Dilihat dari perkembangan awalnya, sejarawan Muslim generasi pertama yang melakukan kajian sejarah terutama tentang sîrah Nabi Muhammad SAW., seperti peperangan dan penaklukan-penaklukannya semata-mata untuk kepentingan dan legitimasi para khalifah dalam menerapkan berbagai kebijakan futûhiyyyah (penaklukan wilayah). Para penulis sejarah awal itu di antaranya adalah 'Urwah bin al-Zubair (w.712 M) yang menulis Sîrah Nabâwîyah, Wahab bin Munabbih (w.728 M) yang menulis sejarah para penguasa Himyar, dan Ibn Syihab al-Zuhrî (w.742 M) yang menulis tentang Magâzî (peperangan Nabi Muhammad SAW), Ibn Ishââ (w.768 M) yang menulis Sîrah Nabâwîyah dan Ibn Mikhnaf (w.768 M) yang juga aktif dalam melakukan kajian-kajian sejarah. ${ }^{20}$ Meskipun karyakarya mereka saat ini tidak lagi bisa dijumpai pada saat ini, namun informasi dari keberadaan karya-karya mereka masih terus diabadikan oleh murid-murid di belakangnya.

Bagi para sejarawan belakangan, inspirasi dari kisah-kisah al-Qur'an dan pemahaman bagi pentingnya menyimpan memori masa lalu, nampaknya telah menuntun pula dalam membangun beberapa teknik pengembangan model penulisan. Kedua model penulisan sejarah di atas, yakni model penulisan sejarah umum seperti sejarah kolektif sosial umat Islam manusia, maupun sejarah individual, yakni studi ketokohan seseorang berupa biografi sahabat dan thabaqât pada akhirnya telah mengarahkan pada perkembangan model penulisan yang lebih khusus lagi tentang ketokohan, yakni karya yang lebih

${ }^{19}$ Kajian khusus tentang historiografi sejarah dalam al-Qur'an mengenai sekira 90 -an tema sejarah diungkap secara lengkap dalam karya bersama Muhammad Jad al-Maula, 'Ali Muhammad al-Bajawî, Muhammad Abû Fazl Ibrâmî dan Sayyid Syahatah. Para penulisnya menyadari pentingnya untuk memudahkan memahami historiografi dalam al-Qur'an. Karena banyak cerita dan peristiwa yang ada di dalam al-Qur'an tidak diceritakan secara utuh baik dalam kitab-kitab tafsir maupun kitab-kitab hadis. Maka untuk memudahkannya mereka susun dalam cerita yang utuh yang sumbernya secara keseluruhan sesuatu yang sudah ada dalam al-Qur'an. Lihat Muhammad Jad al-Maula et al., dalam Qashash al-Qur'ân (Beirut: Dâr al-Jail, 1988); Imâm al-Sya'râwî, Qashas al-Anbiyấ' (Beirut: Dâr 'Ilmiyyah, 2009).

${ }^{20} \mathrm{Namun}$ menurut catatan Ibn al-Nadim dalam al-Fihrasât-nya diduga mereka para pengkaji sejarah awal di antaranya Ziyad bin Abih (w. 53 H), 'Abd Allâh bin 'Abbâs (w. 68 H) dan 'Ubaid bin Syuraih al-Jurhamy (w. 80 H). Lihat Nashshar, Nasy'at al-Tadwîn al-Târikhî, h. 12; al-Ganî, Mu'jam al-Muarrikhîn, h. 8. 
mengarah pada keunggulan seseorang dalam aspek moral dan spiritual atau karâmahnya, yakni hagiografi. ${ }^{21}$ Pola dan model penulisan yang disebutkan terakhir ini, pada akhirnya menjadi semakin menonjol dan menempati posisi penting dalam historiografi Islam.

Kitâb Sîrah Nabawî merupakan bentuk dan model penulisan sejarah individual paling awal dibuat dibanding dengan model penulisan sejarah yang bertemakan sejarah kolektif atau umum. Di tangan Ibn Hisyam (w. 824 M) murid Ibn Ishâa (w. 768 M), tradisi penulisan sîrah begitu populer pada masanya, hal ini berkait erat karena sîrah Nabâwî yang dikembangkannya merupakan bagian penting dari tradisi penulisan hadis, karena informasi yang ditulisnya adalah sebagai bagian yang integral dari keseluruhan kehidupan Nabi Muhammad SAW. sebuah tolak ukur bagi kehidupan beragama (uswah al-h̆hasanah, Q.S. al-Ahzzâb/33: 21). ${ }^{22}$ Sedangkan model sejarah kolektif baru muncul belakangan terutama di tangan Imam Thabarî (w.923 M) dengan Târikh al-Umâm wa al-Mûlûk, ${ }^{23}$ dan al-Tsa'labî (w.1037 M) dengan Qashash al-Anbiyấ. ${ }^{24}$ Kriteria menulis sejarah yang baik menurut al-Sakhâwî adalah keterpaduan antara pengetahuan teks dan berita-berita yang lahir dari kehidupan sosial. Hal ini merupakan contoh dan model dari kompleksitas historiografi Islam yang bisa mewakili corak dari isi karya sejarah, hadis, fikih, kalam dan tasawuf. Semuanya dibutuhkan untuk saling bersinergi dalam memberikan informasi sejarah Islam yang benar. $^{25}$

Dari sekian banyak tulisan sejarah yang telah dilakukan para sejarawan tersebut di atas, baik dalam tema-tema khusus maupun umum, secara tidak langsung telah membentuk

\footnotetext{
${ }^{21}$ Para penulis hagiografi (kitab manâqib) belakangan, mencoba membentuk model baru dalam mengembangkan model penulisan sejarah individual dengan mengkhususkan pada aspekaspek keunikannya. Misalnya kisah-kisah keajaiban yang menyangkut pada diri tokoh-tokoh yang

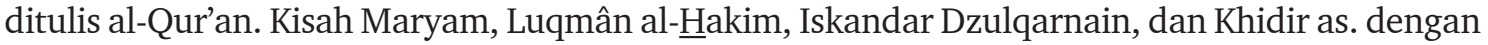
berbagai keunikan karâmahnya, nampaknya telah melatarbelakangi bagi kemunculan model penulisan khusus yang kelak disebut Kitâb al-Manâqib. Karena secara umum model-model penulisan sejarah telah dicontohkan sedemikian rupa dalam al-Qur'an. Lihat, Muhammad Khalâfullâh dalam al-Fann al-Qashshi fĩ al-Qur'ân al-Karîm (Kairo: al-Nahdhah al-Mishriyyah, 1957), h. 118-119.

${ }^{22}$ Al-Sulmî, Manhaj Kitâbah, h. 431-432.

${ }^{23}$ Ibid., h. 544- 550

${ }^{24} \mathrm{Al}-$ Ganî, Mu'jam al-Muarrikhîn, h. 12.

${ }^{25}$ Syams al-Dîn al-Sakhawî, "al-I'lân bi al-Taubîkh li man Dzamma Ahl al-Târikh," dalam Muhammad Kamâl al-Dîn 'Izz al-Dîn 'Alî, Dirâsât al-Naqdiyyat, h. 38-43. Menurutnya, ketika menuliskan sejarah klasik Islam, paling tidak sejarawan harus bersumber pada karya-karya (klasik) berikut al-Mushannaf karya Ibn Abî Syaibah (w. 849 M), Târikh wa Shaĥîh karya al-Bukhârî (w. 870 M), Sunan karya Abû Dâûd (w. 889 M), Murûj al-Dzahab karya al-Mas'ûdî (w. 956 M), al-Aghânî karya al-Ishfahânî (w. 967 M), Târikh al-Rusûl wa al-Mulûk, Tafsîr Jamî' al-Bayân karya al-Thabârî (w. 971 M), al-Shahâh fí al-Lughah karya al-Jauhârî (w. 1003 M), al-Sîrah karya Ibn Faris (w. 1004 M), 'Arâis al-Majâlis karya al-Tsa'alabî (w. 1035 M), Târikh al-Bagdâdî karya Khathib al-Bagdâdî (w. 1072 M), Ihya' 'Ulûm al-Dîn karya al-Gazâlî (w. 1111 M), al-Mu'arrab min Kalâm al-A'jamy karya Ibn Jawaliqî (w. 1145 M), al-Qawâid karya 'Izz al-Dîn 'Abd al-Salâm (w. 1262 M), al-Rawdl, Thabaqât al-Fuqahâ' dan Fadhâ'ih al-Bathiniyyât karya Nawâwî (w. 1278 M), Thabaqât al-Syafi'iyyâh karya Taqî al-Subkî (w. 1355 M).
} 
corak dan modelnya secara sendiri-sendiri. Model-model penulisan sejarah individual maupun sosial, secara metodologis kecenderungannya lebih banyak berkembang dalam bentuk corak penulisan ansâb, sîrah, tarjamah, thabaqât dan manâqib. Bahkan beberapa karya sejarah Islam yang berkembang antara abad ke tiga Hijriyah (9 M) sampai abad ke sembilan Hijriyah (15 M), telah menunjukkan karakter perbedaan yang relatif mencolok dari bentuk awalnya. ${ }^{26}$ Jika pada masa awal tradisi penulisan sejarah seringkali mengikuti seleksi riwayat yang begitu ketat dengan pola dan standar ilmu hadis, maka pada periode berikutnya mereka melakukan penulisan sejarah dengan cara-cara yang lebih mudah dan longgar dalam menyeleksi sumber-sumber. Para sejarawan belakangan biasanya berlaku pula sekaligus sebagai saksi sejarah terhadap objek yang sedang ditulisnya, atau paling tidak mereka hidup sezaman dan dekat dengan apa yang sedang dikajinya, sehingga tampaknya tidak lagi memerlukan beberapa kaidah ilmu riwayat yang ketat. Para penulis sejarah umunya merangkap sebagai pelaku yang terlibat misalnya sebagai sekretaris khalifah, sebagai wazir, tentara, atau orang yang terlibat secara langsung dengan perkawanan komunitasnya seperti halnya para murid-murid dalam sebuah perkumpulan mazhab tarekat sufi, fukaha maupun ahli hadis. Semua itu semakin memudahkan untuk menuliskan apa saja yang ingin diungkapkannya, ${ }^{27}$ sehingga produktivitas karya-karya sejarah semakin beragam dan berkembang lagi.

Munculnya kecenderungan para sejarawan dalam mengungkap secara detil aspekaspek kepribadian seorang tokoh, keagungan akhlaknya, kehebatan karyanya, atau aktivitas kesehariannya, akhirnya secara langsung memberikan peluang baru bagi para peminat dan pengagum tokoh-tokoh mazhab untuk mempromosikan keberadaan tokoh yang dikaguminya secara lebih spesifik dalam berbagai kitab manâqib (hagiografi).

\section{Akar dan Model Penulisan Sejarah Tokoh}

Dalam batas-batas tertentu, ketokohan di dunia Islam sangat diapresiasi oleh merekamereka yang berada di bawahnya, baik itu sebagai pengikutnya, muridnya, atau sebatas sebagai pengagumnya. Berikut ini beberapa model dan akar-akar tradisi penulisan sejarah tokoh dalam historiografi Islam, yang pada akhirnya sedikit banyak memberi pengaruh pada penulisan model kitab manâqib (hagiografi), sebagai sebuah model mutakhir dari studi ketokohan sejarah di dunia Islam.

${ }^{26}$ Al-Sulmî, Manhaj Kitâbah, h. 427.

${ }^{27}$ Beberapa karya yang berkait dengan hal ini misalnya, Sîrah Ahmad Ibn Thûlûn oleh Balawy, Sîrah Ahmad Ibn Thûlûn oleh Ibn al-Dâyat, Sîrah al-Ikhsyîdw oleh Ibn Zawlaq, Akhbâr al-Râdlw wa al-Muttaqw Billah oleh al-Shûlî, Sîrah Shalâh al-Din oleh Ibn Syaddâd, Kitâb al-Raudhatain fĩ Akhbâr al-Daulatain (al-Nûriyah wa Shalâhiyah) oleh Abû Syamah. Lihat Sayyidah Ismâîl Kasyif, Mashâdir al-Târikh al-Islâmî wa Manâhij al-Bahts Fîqh (t.t.p.: Mathba'ah al-Sa'adah, 1976), h. 54. 


\section{Tradisi Penulisan Model al-Ansâb}

Pengagungan terhadap keberadaan nasab (garis keturunan) merupakan tradisi Arab Jahiliyah yang diwarisi kaum Muslim dan menjadi cikal-bakal dalam mengembangkan tradisi ketokohan seseorang. Karena salah satu keberadaan status sosial seseorang terletak pada garis keturunannya. Bagi kebanyakan masyarakat Arab, kebanggaan pada suku merupakan ciri dari keberadaan status sosial yang memilikinya, meskipun pada saat itu (masa-masa pra Islam tradisi) al-ansâb hanya cukup dengan dihafal saja. Bangkitnya penulisan al-ansâb dimulai oleh aliran Irak, ${ }^{28}$ dan menjadi sesuatu yang sangat penting ketika Bani Umayyah di Damaskus kembali melakukan legitimasi politik kearabannya dengan menempatkan posisi status kesukuan Quraisy sebagai pewaris politik dunia Islam satu-satunya yang sah saat itu. Kepentingan ini menjadi semakin kokoh ketika kebijakan arabisme yang digulirkannya menjadi mainstream politik umum, yang ingin menempatkan posisi orang-orang Arab menjadi sentral di pos-pos kekuasaan di wilayah-wilayah luar arab dibanding bangsa-bangsa lainnya.

Meskipun pola penulisan ansâb ini terus berlanjut dalam menggunggulkan ketokohan seseorang, namun setelah abad ke 9 M. kepentingannya lebih bersifat melunak, karena etnik lain di luar Arab dalam tubuh pemerintahan Dinasti Abbasiyah terutama Persia dan Turki cukup dominan. Fungsinya lebih melebar dan mengembang bukan hanya dalam kepentingan politik saja, tapi juga masuk dan membentuk pada garis geneologi keilmuan. Tradisi penulisan al-ansâb ini, kelak akan memberikan pengaruh dalam membentuk jalurjalur genelogi keilmuan atau sanad-sanad keilmuan serta telah menunjang bagi pola penulisan biografi dan hagiografi dalam sejarah Islam. ${ }^{29}$ Kesan ini akan terasa nampak, bila tendensi pengagungan tokoh selalu dimulai dari cikal-bakal keluarga besar atau geneologi keluarga besarnya, guru-guru sebagai sanad (geneologi) periwayatan keilmuan dan sebagainya.

\section{Tradisi Penulisan Mode/ Sîrah dan Tarjamah}

Kata al-sîrah secara semantik adalah perjalanan. Dalam kajian historiografi, alsîrah berarti studi tentang perjalanan kehidupan seseorang, atau biografi seorang tokoh. Nampaknya, munculnya studi tentang sejarah ketokohan di dunia Islam telah dimulai dari tradisi penyanjungan pada seseorang yang berjasa di kalangan masyarakat Arab pra Islam khususnya pada tokoh-tokoh yang muncul di masing-masing kabilah. Mereka mengungkapkan tentang peran yang dilakukannya, nasab keturunannya dan beberapa aspek keistimewaan yang muncul dalam dirinya. Tradisi penyanjungan ini mereka

${ }^{28}$ Diduga tradisi al-ansâb juga berkembang di Irak, karena tradisi kekuasaan Persia kuno menempatkan ketokohan seseorang sebagai raja adalah sesuatu yang harus dikenal dan tidak bisa dimungkiri untuk terus diwariskan pada turunannya. Para turunan inilah tampaknya yang mengambil peran penting untuk mengambil manfaat sekaligus menuliskannya.

${ }^{29}$ Al-Sulmî, Manhaj Kitâbah, h. 445-452. 
ungkapkan dalam berbagai cerita lisan (al-riwâyat al-syafawiyyat) hingga proses penyebarannya cukup mudah untuk bisa dikenal di kalangan masyarakat luas. ${ }^{30}$ Bagi kalangan masyarakat Arab Utara, tradisi penyanjungan ketokohan serta berbagai dinamika kabilah (suku), pada akhirnya lebih dikenal dengan sebutan "ayyâm al-Áab" yang menjadi bagian integral dari carita rakyat Arab atau folklor Arab secara umum. ${ }^{31}$ Namun pada akhirnya isi darifolklor yang ada, bukan lagi hanya cerita tentang ketokohan seseorang di tiap-tiap kabilah, melainkan pula tentang berbagai cerita dan dinamika peperangan antar kabilah itu sendiri. Meskipun pada akhirnya cerita-cerita ini banyak dibumbui dengan berbagai unsur khayal yang bernuansa fiktif dan imajinatif. ${ }^{32}$ Dengan demikian, sebagian dari akar-akar tradisi penyanjungan tokoh ini secara tidak langsung cukup berpengaruh pada historiografi Islam pada masa-masa awal Islam, terutama dalam menempatkan Nabi Muhammad SAW. sebagai pemimpin umat dengan enuh sanjungan. Karena keberadaan dan keteladanan Nabi Muhammad SAW. telah menempati ruang tersendiri secara khusus di mata pengikutnya yang untuk selanjutnya bisa mendorong bagi terciptanya pembuatan dan penulisan sîrah Nabâwî. ${ }^{33}$

Dalam perkembangan berikutnya, tradisi penulisan sejarah semakin lama semakin berpusat pada orang-orang yang memegang kekuasaan. Karena itu, penulisan biografi para khalifah sebagai pengganti Nabi Muhammad SAW. dan orang-orang yang berpengaruh pula dalam memimpin umat sepertinya telah menjadi kecenderungan khusus yang cukup kuat dalam historiografi Islam. Apalagi pada masa Klasik, masyarakat sangat bergantung pada kepemimpinan para seorang tokoh. Kumpulan biografi (siyâr wa tarâjim) tokohtokoh politik, misalnya ditulis oleh Jalâl al-Dîn al-Suyuthî (w. 1505 M), Târîkh al-Khulafâ', 'Alî bin Munjib al-Shair (w. 1147 M), Wuzara'al-Khulafâ al-Fâthimiyyîn (para menteri dari para Khalifah Dinasti Fatimiyah), Ibrâhîm al-Shabî (w. 994 M) menulis Kitâb al-Tâj (buku tentang Mahkota kekuasaan) berisi tentang biografi para penguasa Dinasti Bani Buwaihi, ㅂilâl al-Shabî (w.448 H/1056 M) menulis Kitâb al-Wuzarâ' (buku tentang Para Menteri). ${ }^{34}$

Perbedaan yang paling mencolok antara model penulisan sîrah dan tarjamah, jika yang pertama dalam menggambarkan biografi kehidupan seorang tokoh diuraikan secara lebih luas dan mendalam, sehingga seringkali muncul dalam satu buku tersendiri, hal ini terlihat misalnya dari berbagai bentuk sîrah al-Nabâwîyah yang sangat lengkap dan dalam. Sedangkan tarjamah adalah model penulisan tokoh yang polanya bersifat ensiklopedis, ringkas, padat dan mencakup aspek-aspek penting tertentu dari tokoh yang digambarkannya. Tradisi penulisan tarjamah tampaknya telah dimulai dan digunakan

\author{
${ }^{30}$ Ibid., h. 456. \\ ${ }^{31}$ Ibid., h. 454. \\ ${ }^{32}$ Kasyif, Mashâdir al-Târîkh, h. 12. \\ ${ }^{33}$ Al-Sulmî, Manhaj Kitâbah, h. 456-457. \\ ${ }^{34}$ Badri Yatim, Historiografi Islam (Jakarta: RajaGrafindo Persada, 2003), h. 208
}


untuk mengisi berbagai materi tentang ketokohan seseorang di berbagai kitab thabaqât. ${ }^{35}$ Kedua model penulisan ini, sedikit banyak akan memengaruhi dan menginspirasi bagi penulisan manâqib yang muncul pada masa-masa di belakangnya.

\section{Tradisi Penulisan Mode/ Thabaqât}

Pola penulisan riwayat hidup yang muncul dalam kitab-kitab thabaqât, sedikit banyak telah menginspirasi terhadap penulisan manâqib. Keunggulan yang muncul karena ia memiliki klasifikasi yang jelas dalam mengurutkan posisi seseorang. Arti kata thabaqât secara semantik adalah lapisan atau kurun. ${ }^{36}$ Pada perkembangan awal pembentukan dan penulisannya, pengertian thabaqât berarti sejumlah kumpulan tentang informasi berbagai biografi tokoh-tokoh periwayat hadis yang didasarkan pada pelapisan generasinya. Sebuah konsekuensi dari konsep penghormatan akan keberadaan orang-orang yang berada di sekitar Nabi Muhammad SAW., setingkat generasi para sahabat, tabiin, tabiittabiin dan seterusnya, yang berkedudukan sebagai perawi hadis. Keberadaan mereka menjadi sesuatu yang sangat penting bagi keberadaan status hadis, sehingga para ahli hadis perlu menuliskannya secara lengkap seluruh informasi tentang status ketokohan dan keberadannya. ${ }^{37}$

Karena jumlah biografi para tokoh ini sangat banyak, maka sejak awal perkembangannyapun dalam penulisan thabaqât sudah mengenal pembagian tokoh yang akan diceritakannya berdasarkan wilayah domisilinya dan profesi kelompoknya semacam Thabaqât Syâfi'iyyah, Thabaqât Hanâbilah, Thabaqât al-Shûfiyyah, Thabaqât al-Thibba', Thabaqât al-Syu'arâ, dan Thabaqât al-Nahwiyyîn. ${ }^{38}$ Dalam historiografi Islam, penulisan model thabaqât merupakan model yang paling terus bertahan dan cukup digemari para ahli hingga kini, karena telah memberikan sumbangan yang sangat jelas dalam memetakan dan menginformasikan kedudukan tokoh-tokoh Islam, baik sebagai perawi hadis, ulama mazhab (baik fikih dan tasawuf) maupun sebagai tokoh-tokoh lain dalam posisi keilmuan tertentu. Kitab thabaqât lebih memudahkan dalam pencarian indeks ketokohan, keahlian

${ }^{35}$ Lihat misalnya karya al-Sulâmî, Thabaqât al-Shûfiyyah dan al-Sya'rânî, Thabaqât al-Kubrâ.

${ }^{36}$ Mungkin mereka terpengaruh oleh ayat al-Qur'an (Q.S. al-Insyiqâq/84:19) "latarkabûnna thabaqa 'an thabaq," mereka berjalan berbaris di yaum al-akhîr berdasarkan kelompok-kelompok. Q.S. al-Mulk/67: 15, "sab'a samâwât thibâqa". Para ahli leksikografi mencoba menetapkan batasan yang pasti dalam menentukan antara satu generasi dengan generasi lainnya dalam sebuah thabaqât. Sebagian mereka menentukan lapisan generasi per-dua puluh tahunan, per-empat puluh tahunan, bahkan ada juga yang menyatakan bahwa antara thabaqât berjarak sepuluh tahun. Lihat, Muhammad bin Abû Bakar bin 'Abd al-Qadîr al-Râzî, Mukhtâr al-Shihahah (Beirut: Dâr Fikr, t.t.), h. 388.

${ }^{37}$ Al-Sulmî, Manhaj Kitâbah, h. 454.

${ }^{38}$ Muhammad Ibn Sa'ad misalnya dalam karyanya sudah mencantumkan secara khusus bab-bab tertentu mengenai orang-orang Kufah dan Bashrah. Meskipun mereka telah diulas dalam bab-bab lain, namun penjelasan tentang para sahabat yang mempunyai hubungan dengan Kufah dan Bashrah ia ulas kembali. Lihat H. A. Muin Umar, Historiografi Islam (Jakarta: Rajawali Press, 1988), h. 49-51. 
dan posisi sosialnya. Bahkan dalam klasifikasi al-Dzahabî dan al-Sakhawî, masuk pula klasifikasi biografi tokoh-tokoh lainnya, seperti kelompok orang kaya, kelompok para pengemis, kelompok para pemberani, dan kelompok para ahli nujum. ${ }^{39}$ Penulisan tentang tokoh-tokoh sufi dan fikih telah menempati posisi yang cukup sentral pula dalam tradisi penulisan thabaqât ini, al-Ishfahânî menulis Hilyat al-Awliyâ' wa Thabaqât al-Ashfiya', al-Sya'ranî menulis Thabaqât al-Kubrâ yang juga berisi riwayat hidup para sufi dari generasi ke generasi.

Tradisi penulisan kitab manâqib di kalangan ahli kalam dan filsafat Islam, kurang populer, meskipun di antara tokoh-tokoh mereka memiliki popularitas dan pengaruh keilmuan yang cukup tinggi. Mereka tampaknya lebih senang mengembangkan penulisan sejarah tokohnya dalam bentuk yang relatif datar atau sederhana, seperti halnya karya sejarah model kitab tarjamah atau thabaqât. Realitas semacam ini nampaknya sebagai akibat pengaruh rasionalisme dalam menggambarkan atau menjelaskan setiap tokoh sebagai objek ilmu. Sehingga hampir sulit ditemukan jenis-jenis karya biografi setingkat kitab manâqib yang menggambarkan tokoh-tokoh kalam atau ahli tafsir sekalipun. Kitabkitab manâqib seolah-olah sejak abad ke $13 \mathrm{M}$, telah menjadi milik para kalangan imamimam atau syaikh-syaikh terkenal dari kalangan sufi atau fikih saja. Selama ini meskipun mereka banyak dikenal seperti halnya Imam al-Asy ârî, Imam al-Gazâlî atau yang lainnya sebagai tokoh Islam yang berlatar belakang sebagai filosof, biografinya dan penjelasannya digambarkan sebagai sesuatu yang datar dan sederhana, tidak banyak melibatkan kekarâmahannya. Pola kehidupan al-Gazâlî banyak ditemukan hanya dengan penjelasan yang biasa saja, tidak menampilkan hal-hal yang 'khawâriq' dan aneh. ${ }^{40}$

Berikut ini sekilas persamaan dan perbedaan antara kitab sîrah, tarjamah, thabaqât dan manâqib, mengenai objek kajiannya, tema pembahasannya, struktur penulisannya, dan fokus pembahasannya. Lebih jelas bisa dilihat dalam tabel berikut ini:

${ }^{39}$ Yatim, Historiografi Islam, h. 202-203.

${ }^{40}$ Abû Hamîd al-Gazâlî, Ihya' 'Ulûm al-Dîn. h. 251 


\section{Model-model Historiografi Ketokohan}

\begin{tabular}{|c|c|c|c|c|}
\hline $\begin{array}{c}\text { Model } \\
\text { Historiografi }\end{array}$ & Struktur & Objek & Tokoh & Fokus \\
\hline Kitâb Sîrah & $\begin{array}{l}\text { Kelahiran, keluarga, } \\
\text { perjuangan, keber- } \\
\text { hasilan dan kemati- } \\
\text { an }\end{array}$ & $\begin{array}{l}\text { Nabi } \\
\text { Muhammad } \\
\text { SAW. }\end{array}$ & Personal & $\begin{array}{l}\text { Perjalanan hidup yang } \\
\text { lengkap dan dalam } \\
\text { (edisi khusus tentang } \\
\text { tokoh sejarah). }\end{array}$ \\
\hline Kitâb Thabaqât & $\begin{array}{l}\text { Sepintas kelahiran } \\
\text { dan pendidikan, } \\
\text { keistimewaan, } \\
\text { keahlian, pemikiran }\end{array}$ & $\begin{array}{l}\text { Sahabat, } \\
\text { komunitas } \\
\text { ilmu, dan } \\
\text { mazhab. }\end{array}$ & $\begin{array}{l}\text { Komunal } \\
\text { Personal }\end{array}$ & $\begin{array}{l}\text { Pengelompokan kehi- } \\
\text { dupan generasi, profesi } \\
\text { keahliannya atau } \\
\text { mazhab. }\end{array}$ \\
\hline Kitâb Tarjamah & $\begin{array}{l}\text { Kelahiran, sepintas } \\
\text { perkembangan, } \\
\text { perjuangan, keahlian } \\
\text { dan kematian }\end{array}$ & $\begin{array}{l}\text { Tokoh } \\
\text { tertentu, } \\
\text { biografi } \\
\text { umum. }\end{array}$ & Personal & $\begin{array}{l}\text { Biografi singkat sese- } \\
\text { orang. Digunakan } \\
\text { dalam pengenalan } \\
\text { ringkas (ensiklopedik). }\end{array}$ \\
\hline Kitâb Manâqib & $\begin{array}{l}\text { Sepintas kelahiran, } \\
\text { perjalanan keilmuan, } \\
\text { keistimewaan kepri- } \\
\text { badian (husn al-hâal), } \\
\text { karâmah, nasehat, } \\
\text { perjuangan, dan } \\
\text { ajaran. }\end{array}$ & $\begin{array}{l}\text { Tokoh- } \\
\text { tokoh sufi } \\
\text { dan fikih. }\end{array}$ & Personal & $\begin{array}{l}\text { Kumpulan karâmah } \\
\text { tokoh (wali dan fakih, } \\
\text { syaikh, imam), keisti- } \\
\text { mewaan, kepribadian, } \\
\text { keteladanan, ajaran. } \\
\text { Bersifat empirik dan } \\
\text { non-empirik, } \\
\text { spiritualitas (historis } \\
\text { dan meta-historik). }\end{array}$ \\
\hline
\end{tabular}

\section{Tradisi Manâqib dalam al-Qur'an dan Hadis}

Dalam al-Qur'an banyak sekali jenis-jenis ungkapan penyanjungan atau hagiografi terhadap tokoh-tokoh sejarah, realitas ini nampaknya kelak mendasari bagi pola pengembangan penulisan kitab manâqib. Ungkapan-ungkapan al-Qur'an mengenai tokoh-tokoh sejarah yang dijelaskannya, bukan hanya sekedar diungkapkan dengan penceritaan biasa namun seringkali diikuti dengan cara-cara penyanjungannya. Hal ini dilakukan bukan hanya kepada para Nabi saja, tapi juga pada tokoh-tokoh tertentu yang kapasitasnya bukan sebagai Nabi, seperti halnya pada Luqmân al-Hakîm, Maryam binti 'Imrân, Ashof bin Barkhiya as. pembantu Nabi Sulaiman as., dan Ashâab al-Kahfi. ${ }^{41}$

Tradisi menuliskan keistimewaan orang-orang tertentu mungkin sejak awal telah dimulai oleh Imam al-Bukhârî (w. 870 M) sebagai ahli hadis dalam karyanya yang cukup terkenal, Kitâb Shahîh $\underline{h}$ al-Bukhârî. Ia telah menulis bab khusus tentang hadis-hadis yang menggambarkan keistimewaann para sahabat Nabi Muhammad SAW. dengan judul Bâb al-Fadhâ'il Ashhূâb al-Nabi, Bâb al-Manâqib al-Muhâjirîn, dan Bâb al-Manâqib al-Anshâr. Dalam bab-bab tersebut ia telah merekam tentang sanjungan dan komentar baik Nabi

41Yûsuf al-Nabhanî, Jâmi’ al-Karâmah, Juz I (Beirut: Dâr Fikr, 1989), h. 34. 
Muhammad SAW. terhadap beberapa prestasi sahabat yang disebutkan dalam kumpulan hadisnya tersebut. Dalam konteks ini nampaknya ia sebagai tokoh yang dianggap paling awal dalam mempopulerkan istilah dan kata 'al-manâqib,' untuk menunjuk keistimewaan atau sesuatu yang dianggap istimewa dalam diri seseorang. Dalam hal ini para sahabat Nabi Muhammad SAW. yang digambarkan dan disebutkan secara khusus dalam hadishadis dengan sifat-sifat dan karakter yang istimewa. ${ }^{42}$ Selanjutnya Abû al- $\underline{\text { Husain Muslim }}$ bin ㅂajâj (w. 261 H) penulis Kitâb Shaĥîh Muslim, mengumpulkan pula beberapa hadis yang berkait dengan keistimewaan beberapa sahabat Nabi Muhammad SAW. dan menuliskannya dengan Kitâb Fadhâ'il al-Shahâbah Radhiyallâh 'anh. ${ }^{43}$ Imam al-Tirmizî (w. 279 H) penulis Kitâb Jâmi' al-Shâhîh $\underline{h}$ di dalamnya juga mencantumkan 'Abwâb alManâqib 'an Rasulillâh SAW.'44

Pada dasarnya hadis-hadis tentang manâqib para sahabat yang dikumpulkan oleh ketiga tokoh ahli hadis (Bukhârî, Muslim dan Tirmizî) tersebut tidak menunjukkan perbedaan yang signifikan, baik dari segi redaksi maupun isinya. Karena beberapa rawi yang dijadikan sumber dalam memunculkan hadis-hadis tentang manâqib sahabat masih dari sumber yang sama. Namun dari sisi penamaan judul-judul bab yang menyangkut tentang manâqib mereka, ditulis dengan redaksi yang cukup variatif.

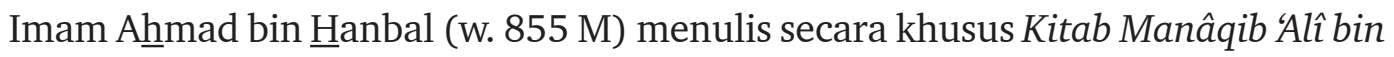
Abî Thâlib, yang didasarkan pada hadis dan atsar sahabat. ${ }^{45}$ Selanjutnya Imam al-Khawarizmî (w. 1173 M) menulis juga kitab hadis yang secara khusus tentang orang-orang yang paling dekat dengan Rasululah SAW. dengan judul Kitâb al-Manâqib al-Khawârizmy li Alîbin Abî Thâlib. Karya kitab hadis yang lebih memotret pada keluarga dekat ini pada akhirnya menjadi rujukan penting bagi kalangan Syi'ah karena telah menguatkan dan menjadi legitimasi dalam menjelaskan tentang informasi dan posisi keluarga Nabi Muhammad SAW. berikut keistimewaannnya. ${ }^{46}$

Perkembangan berikutnya objek menuliskan keistimewaan seseorang bukan lagi milik para sahabat, tapi juga milik semua umat Islam yang secara turun-temurun biasanya

\footnotetext{
${ }^{42}$ Karakteristik penulisan kitab manâqib dari kalangan muhadditsîn, dipandang sangat orisinil karena ia masih berupa teks-teks hadis yang dikelompokkan secara khusus atas dasar isi matan teks yang sudah dikategorikan khusus dalam membahas keistimewaan para sahabat, dan yang memiliki kaitan khusus dengan penghargaan Nabi Muhammad SAW. Misalnya hadishadis tentang para sahabat Nabi Muhammad SAW. yang dijanjikan masuk surga, yang mendapat sanjungan Nabi Muhammad SAW. Lihat Ch. Pellat, "Manâqib," dalam the Encyclopaedia of Islam (Leiden: Koninklijke Brill. NV, t.t.), h. 1-5.

${ }^{43}$ Imâm al-Nawâwî, Shaĥîh Muslim bi Syarh Imâm al-Nawawy, Juz 4 (Bandung: Maktabah Dahlan Bandung, t.t.), h. 1854.

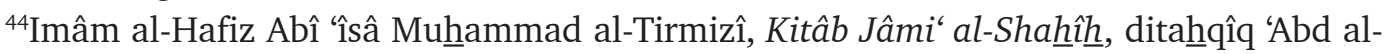
Wahhab bin 'Abd al-Lathif (Semarang: Maktabah Thoha Putra, 1967), h. 243.

${ }^{45} \mathrm{Hâji} \mathrm{Khalîfah,} \mathrm{Kasyf} \mathrm{al-Dzunûn} \mathrm{'an} \mathrm{Usamy} \mathrm{al-Kutub} \mathrm{wa} \mathrm{al-Funûn,} \mathrm{Jilid} \mathrm{II} \mathrm{(Beirut:} \mathrm{Dâr}$ Fikr, 1993), h. 677; Pellat, "Manâqib," h. 7-9.

${ }^{46}$ Karya al-Khawarizmî ini dicetak di Iran oleh Mathba‘ah Nainawah al-Hadîtsah, Teheran.
} 
berurut dari sahabat diikuti keistimewaannya oleh para tabiin dan orang-orang saleh berikutnya. Historiografi mengenai orang-orang saleh secara riil akhirnya mengarah pada sejumlah tokoh-tokoh sufi yang memiliki keistimewaan tertentu, yang biasa disebut karâmah. Sehingga karâmah-karâmah mereka telah menjadi subjek pembahasan yang sangat menarik bagi para pembaca dan digemari dalam berbagai penulisan kitab manâqib. Tradisi penulisan tentang karâmah para wali di dunia Islam, sebagaimana halnya juga tentang objek kajian yang lainnya seperti tema-tema yang muncul dalam bidang fikih, kalam, sejarah dan sebagainya, nampaknya memiliki inspirasi dan korelasi yang cukup kuat dari modelmodel yang telah dicontohkan dalam al-Qur'an maupun hadis sebagaimana yang telah disebutkan. Keberadaan mukjizat dan karâmah sebagai wacana keagamaan, dasarnya bukan hanya telah tercantum dalam al-Qur'an, tapi juga telah dituliskan dan diungkapkannya secara nyata dan langsung pada berbagai kitab hadis dengan contoh-contoh penulisanya. ${ }^{47}$

Dengan demikian, lahirnya berbagai bentuk dan contoh yang beragam tentang model penulisan manâqib di beberapa hadis tersebut, termasuk juga beberapa atsar sahabat Nabi Muhammad SAW. yang menjelaskan di dalamnya, membuktikan bahwa tradisi penulisan dalam historiografi Islam mengenai objek dan tema-tema tentang mukjizat, karâmah, dan barâkah yang dikaitkan dengan ketokohan seseorang sangat kuat dan populer serta faktual dalam tradisi penulisan kitab-kitab manâqib berikutnya. ${ }^{48}$

\section{Penulisan Ketokohan di Kalangan Mazhab Fikih dan Sufi}

Dalam perkembangan selanjutnya, tradisi penulisan tentang sejarah kemanusiaan yang lebih detil dan lebih luas lagi dengan tema lain yang juga mirip dan dekat dengan jenis tema penulisan karâmah, nampak masih terus bermunculan pada masa-masa berikutnya. Seperti halnya tentang Kitâb al-Fadhâil (studi tentang keunggulan seseorang) Kitâb al-Mahâasin (studi tentang kebaikan seseorang) karya sejarah yang menceritakan dan merefleksikan bentuk keistimewaan seseorang dalam sejarah kehidupannya. Semua tema-tema ini, dianggap cukup mewarnai pula dalam perkembangan historiografi Islam. Mungkin secara terminologis jenis-jenis kitâb al-mahâasin atau kitâb al-fadhâil lebih mirip sebagai sesuatu yang menggambarkan ma'unah (pertolongan Allah) pada diri seseorang yang dianggap saleh. ${ }^{49}$ Semua fenomena yang digambarkan di dalamnya nampaknya sebagai sesuatu yang mirip dengan jenis karâmah yang secara umum banyak bermunculan di kalangan para wali dan orang-orang saleh yang menjauhi segala perbuatan maksiat. Kepentingan dan manfaat mengenai tulisan tentang hal ini, nampaknya lebih mengarah pada dimensi dakwah dan hujah bagi kebenaran dan refleksi dari keagamaan seseorang,

${ }^{47}$ Abd al-Qadir 'Îsâ, Haqâiq 'an al-Tashawwuf (Syiria: Dâr Ma'ârif Suriah Halab, 2001), h. 361.

${ }^{48}$ Hamid al-Husain, Peristiwa Gaib, Barakat dan Mukjizat Kenabian Muhammad SAW (Bandung: Pustaka Hidayah, 2006).

${ }^{49}$ Pellat, "Manâqib," h. 1-15. 
sehingga banyak mendorong para penulis untuk memotret dan menuangkannya pada bentuk tulisan.

Meskipun jenis dan model tulisan yang disebutkan terakhir ini tidak sepopuler dengan model penulisan karâmah, namun cukup mewarnai juga dalam ranah historiografi Islam klasik dan menjadi jenis tersendiri karena objeknya yang relatif cukup banyak, meliputi banyak jenis orang yang bisa disaksikan dalam setiap ruang dan waktunya. Sementara penulisan karâmah, nampaknya lebih dikhususkan dan lebih spesifik hanya terjadi pada wali Allah saja, yakni orang-orang mencintai dan dikasihi Allah SWT. secara istimewa, karena keimanan dan ketakwaannya yang tulus dan ikhlas ${ }^{50}$ sebagaimana yang dinyatakan dalam Q.S. Yûnus/10: 62-64 yang artinya "Ingatlah, sesungguhnya wali-wali Allah tidak ada kekhawatiran pada diri mereka dan mereka tidak bersedih. Mereka adalah orang-orangyang senantiasa beriman dan bertakwa. Mareka selalu diliputi kegembiraan dalam kehidupan dunia dan akhirat...". Keberadaan para wali ini berdasarkan hadis-hadis Nabi Muhammad SAW., selalu muncul di setiap zaman hingga hari akhir. ${ }^{51}$

Dalam membangun tema penulisan tentang karâmah, para ahli di bidang ini akhirnya telah menyepakati sebuah "model baru" yakni jenis tulisan yang lebih mengkhususkan untuk menceritakan keistimewaan dan kehidupan tokoh-tokoh sufi terkenal, yakni para wali Allah denga beberapa karâmahnya. Karya khusus ini selanjutnya menjadi populer dengan sebutan kitâb al-manâqib. Mengapa tradisi penulisan tentang keagungan seseorang (hagiografi) atau gambaran tentang karâmah seorang wali atau wali-wali tertentu pada akhirnya menjadi banyak diminati para penulis? Mungkin ada kaitannya terutama setelah mendapat pembenaran dan pengakuan dari teologi Asyariyyah yang mengakui akan adanya tradisi ziarah kepada para wali dan pembangunan terhadap makam-makam mereka. Perkembangan dan kegiatan intelektualitas penulisan manâqib para wali di dunia Islam tersebut terjadi terutama sejak abad ke $4 \mathrm{H} / 10 \mathrm{M}$, dan tradisi penulisannya kebanyakan dilakukan dan berada di sekitar makam para wali tersebut baik oleh para penjaga makam atau oleh murid-murid yang mengaguminya. ${ }^{52}$ Nama-nama kitab mereka kebanyakan dinamai dengan sebutan kitâb al-manâqib, akar kata dari "manqabah", yakni lorong atau lubang untuk mengintip keitimewaan seseorang secara khusus. ${ }^{53}$ Kata "manâqib" jamak

\footnotetext{
${ }^{50}$ Lihat pengantar Ibrâhîm 'Uthwah 'Audh pada karya Yûsuf bin Ismâ'îl al-Nabhanî, Jâmi' Karamat, h. 7-8.

${ }^{51}$ Berdasarkan hadis yang diketahui riwayatnya dari 'Umar bin Khaththâb menyatakan "dalam umatku senantiasa terdapat sekelompok orang yang selalu menampakkan kebenaran (takwa) hingga datang hari akhir" (H.R. al-hakîm). Al-Suyuthî, Jâmi' al- Shâgir, Juz VII (Beirut: Dâr al-Khair, t.t.), h. 271. Hadis ini diriwayatkan pula oleh para ahli hadis sepert al-Darâmî dalam Musnad al-Firdausi, Bukhârî dalam sejarah, Abû Ya'la, al-Hakim, al-Dhiya' seluruhnya menyandarkan sanadnya kepada 'Abd Allâh Ibn 'Umar. Lihat Sa'id 'Abd al-Fatah, Karâmât al-Awliyâ', h. 47.

${ }^{52}$ Henri Chamber-Loir \& Clude Guillot, Ziarah dan Wali di Dunia Islam (Jakarta: Serambi Ilmu Semesta, 2007), h. 532-535; Pellat, "Manâqib," h. 7-9.

53Ibn Mandzur, Lisân al-Arab, Juz I (Beirut: Dâr Fikr, t.t.), h. 765.
} 
dari kata "manqabah," dan kata jamak ini lebih populer dalam penggunaannya di berbagai jenis penulisan tentang karâmah.

Mengapa ada kecenderungan bahwa karâmah itu harus dilihat secara khusus, tidak sebagaimana peristiwa-peristiwa lain yang berlaku dalam kehidupan sejarah manusia secara umum, sehingga ia mesti dipotret secara lebih khusus lagi? Karena peristiwa istimewa yang disebut karâmah, nampaknya tidak akan terjadi terhadap manusia biasa kecuali bagi para wali Allah, lagi pula tidak memungkinkan untuk terus-menerus dipertunjukkan di depan umum. ${ }^{54}$ Maka para ahli dibidang ini nampaknya telah menyadarinya, sehingga harus dilihat dan diangkat secara khusus. ${ }^{55}$ Jika pengetahuan yang biasa menjelaskan gambaran kehidupan anak-anak manusia secara umum atau yang terjadi dalam kehidupan anak manusia biasa lebih sering disebut biografi atau tarjamah, maka pilihan peristiwa yang khusus ini lebih banyak disebut hagiografi atau manâqib.

Sekalipun demikian, secara umum cara-cara kerja mereka dalam melakukan kajian dan penulisan tentang keunggulan tokoh-tokoh tersebut, sebagaimana yang biasa dilakukan oleh para penulis sejarah umum lainnya. Kebiasaan atau langkah-langkah penelitiannya yang berlaku misalnya dengan menerima kesaksian dari orang-orang yang pernah merasakan dan terlibat langsung dalam peristiwa tersebut, atau melalui penuturan dari pelaku sendiri yang juga banyak orang menyaksikannya yang umumnya adalah murid-murid, atau melalui berita-berita yang tersebar luas di masyarakat. Secara umum, dalam setiap langkah kehidupannya dalam waktu dan situasi tertentu telah melahirkan keluarbiasaan. Karena setiap pemilik karâmah, terkadang tidak mengetahui atau tidak menyadarinya bahwa sesuatu yang dilakukannya dijalankannya mengandung sebuah karâmah. ${ }^{56}$ Mungkin selama dalam kehidupannya ia juga merasakan beberapa hal peristiwa-peristiwa ganjil itu.

Peristiwa terjadinya karâmah, pada umumnya juga sangat singkat, sebagaimana halnya juga peristiwa-persitiwa lain yang terjadi dalam momen-momen penting sejarah seperti halnya peristiwa kelahiran, peperangan, pembunuhan, dan kematian. Namun demikian, bentuk peristiwa karâmah adalah sesuatu yang tidak biasa terjadi dalam kehidupan nyata manusia secara umum, namun lebih merupakan keistimewaan pada orang-orang tertentu. ${ }^{57}$ Karenanya, fenomena karâmah telah mengundang beberapa

${ }^{54}$ Al-Nabhanî, Jâmi’ Karâmat, h. 5-7.

${ }^{55}$ Sarâj al-Thûsî, Kitâb al-Luma' (Beirut: Dâr Kutub al-'Tlmiyah, 2001), h. 275.

${ }^{56}$ Ibid., h. 282.

${ }^{57}$ Karena itu bagi kalangan ahli kalam, sebagian ada juga mempersoalkan dan mengkritisi akan keberadaannya, kenapa keramat tidak banyak muncul dari kalangan para sahabat Nabi Muhammad SAW., tapi lebih banyak muncul dari kalangan para wali sufi, yang kehidupannya lebih kemudian? Dalam hal ini, Imam Taj al-Dîn al-Subkî memberikan alasan, bahwa masa-masa periode kenabian atau masa sahabat, keimanan akan nilai keagamaan sangatlah kuat sejalan dengan amaliyah mereka dalam menjalankan ibadahnya. Mungkin di kalangan mereka hal-hal yang berkaitan dengan peristiwa karâmah, bisa juga seringkali muncul, namun tidak banyak diungkapkan dalam 
ulama untuk menuliskan dan menjelaskannya, baik secara filosofi, syariat maupun hakikatnya, dalam berbagai karya yang berjilid-jilid. Mereka yang menuliskannya, pada umumnya adalah orang-orang yang mengakui akan keberadaan karâmah yang terjadi pada seorang yang saleh yang biasa disebut waliyullah. Abû Bakar al-Baqillânî, Imam al-Haramain, Abû Bakar bin Fauroq, Abû Hamid al-Gazâlî, Nashr al-Dîn al-Baidhawî, Hafidh al-Dîn al-Nasâfî, Tajd al-Dîn al-Subkî, Abû Bakar al-Asy‘arî, dan al-Nawâwî kesemuanya menunjukkan wawasan dan argumentasinya yang kuat, dalam memberi kepastian akan keberadaan karâmah sebagai bagian dari fenomena dan bagian integral dari keyakinan dan sekaligus pengalaman keagamaan anak manusia. ${ }^{58}$

Beberapa penulis berikutnya yang berada di bawah mereka masing-masing ulama jumhur tersebut, pada umumnya kemudian mengembangkan karya tulisannya berdasarkan ciri khas dan dari sudut keahlian masing-masing. Secara tidak langsung kehadiran beberapa tulisan tersebut telah memberikan kontribusi yang cukup besar terhadap kemunculan dan menunjang keberadaan beberapa kitab-kitab manâqib berikutnya. Semua yang telah dijelaskan ini, menunjukkan tingkat kompleksitas bahwa antara satu karya dengan karya yang lainnya akan saling berkait, menguatkan bahkan saling mendukung. Di antara kitab-kitab yang berkait dengan pembahasannya menyangkut dengan persoalan-persoalan keramat para wali tersebut di antaranya, ${ }^{59}$ Abû Qasim al-Qusyairî (w. 465 H) al-Risâlah al-Qusyairiyyah, Usamah bin Munqidz (w. 584 H) Kitâb al-I'tibâr, Fakhr al-Dîn al-Râzî (w. 606 H) Ahâdits al-Mu'jizat al-Mi'ah al-Atiyah dan al-Tafsîr al-Kabîr, Imam Wali al-Dîn alTabrîzî Misykât al-Anwâr yang ditulis tahun 737 H.; Abû 'Abd Allâh bin Nu'mân al-Marakesy (w.683) Misbâh al-Dzulâm fí al-Mustagîtsîna bi Khair al-Anâm, Syaikh Muhy al-Dîn Ibn 'Arabî (w. 636) Ruh al-Quds, Mawâqi' al-Nujûm dan Futûhât al-Makiyyat, Imam al-Yafi'î (w.768 H), Raudh al-Riyahîn dan Nasyr al-Mahââin dan Kamâl alDîn Muhammad bin Abî Hasan al-Rifa'î al-Syâfi'î, Yûsuf bin Ismâ'îl al-Nabhanî (w. 1350 H) yang menulis Jâmi' Karâmat al-Awliyâ'. ${ }^{60}$

Berbagai kajian dan tulisan tentang karâmah bukan hanya lahir di kalangan kelompokkelompok sufi, tapi juga sebaliknya di kalangan orang-orang yang cenderung kritis untuk menolak keberadaan karâmah para wali seperti halnya kaum Wahabiyyah juga ikut meramaikan wacana di dalamnya sehingga secara umum, pola dan karakteristik model-

berita atau pun tulisan, karena mungkin sebagai hal yang biasa terjadi. Argumentasi-argumentasi semacam karâmah bagi para generasi berikutnya yang sebagian besar sedang mengalami krisis keimanan dan mentalitas keagamaan yang menurun, nampak sangat diperlukan dan dibutuhkan kemunculannya pada tokoh keagamaan yang sedang mengajak ke jalan kebenaran, dan semua yang terjadi pada mereka tentunya selalu didasarkan sebagai penguat dari misi kenabian yang sedang dijalankannya. Karena itulah mu'jizat dan karâmah seringkali dipandang dan terjadi pada saat-saat dibutuhkan oleh si penerimanya. Al-Nabhanî, Jâmi’ Karâmat, h. 20.

${ }^{58}$ 'Abd al-Qadîr 'Îsâ, Haqâiq 'an al-Tashawwûf, h. 369-370.

${ }^{59}$ Al-Nabhanî, Jâmi’ Karâmat, h. 9-11.

${ }^{60} I b i d .$, h. 5-7 
model historiografi dalam bidang karâmah ini semakin menambah jumlah yang cukup kompleks. ${ }^{61}$ Produktivitas karya oleh masing-masing komunitas seperti disebutkan sebagian di antaranya di atas telah diisi oleh mereka-mereka dengan latar belakang sebagai sufi, fukaha atau ahli kalam bahkan para filosof. Mereka terkadang membicarakannya dengan saling bersitegang, atau sebaliknya untuk saling melengkapi. ${ }^{62}$ Bagi kalangan Mu'tazilah, memandang karâmah bukanlah sebagai sesuatu yang luar biasa bagi seseorang sehingga dalam pandangannya, fenomena karâmah mereka anggap sebagai sesuatu yang harus bisa didekati secara rasional. ${ }^{63}$

Hampir bisa dipastikan, bahwa tradisi penghormatan dan pengagungan kepada para ahli ilmu dan tokoh-tokoh penting di kalangan komunitas keilmuan dan para akademisi Muslim merupakan awal dari tradisi penulisan berbagai bentuk biografi dengan berbagai macam dan coraknya. Di samping sîrah Nabâwî yang memang lahir lebih awal sebagai cikal bakal dan standar dalam melakukan pengagungan pada ketokohan seseorang, dorongan kewahyuan yang dicontohkan al-Qur'an sendiri yang mempopulerkan tokoh-tokoh penting sejarah, nampaknya sebagai sesuatu yang tidak bisa diabaikan sama sekali dalam mengilhami munculnya tradisi penulisan dibidang ini. ${ }^{64}$ Meskipun di balik itu tampak pula beberapa hal yang sulit dihindari yakni sikap-sikap psikologis untuk memunculkan dan menampilkan bendera-bendera mazhab bagi kalangan tertentu. Para murid yang terus bersikukuh untuk membangkitkan loyalitas dan komunalitas sebuah perguruan atau lembaga-lembaga di mana mereka berkumpul dalam menggali pemikiran dan gagasan-gagasan para guru besarnya, dalam aspek-aspek tertentu terkadang tidak disadari telah memberi andil yang begitu besar dan memiliki peranan penting untuk memainkan kesadaran kultural dalam pembentukan dalam penulisan biografi atau yang lebih spesifik berbentuk kitab-kitab manâqib. ${ }^{65}$

Gerakan penulisan jenis biografi (tarjamah) bagi ketokohan seseorang, secara kategoris bisa dibedakan dalam dua model aktualisasi. Pertama, bilamana tokoh yang digambarkannya lebih bersifat apa adanya dalam memberikan pengaruh bagi muridmuridnya, pada umumnya cukup dituliskan dalam bentuk sebuah sîrah atau tarjamah saja, dengan tidak terlalu mengungkapkan aspek-aspek keluarbiasaannya. Sejarah tokoh model ini, umumnya hanya mengungkapkan keberhasilan intelektualitasnya, karirnya, murid-muridnya dan sebagainya. Umumnya mereka ditulis dalam kitab-kitab yang bersifat ensiklopedis seperti kitab-kitab thabaqât, mu'jam, dan tarajim. ${ }^{66}$

Kedua, bila peran ketokohan seseorang nampak lebih besar dalam membangun

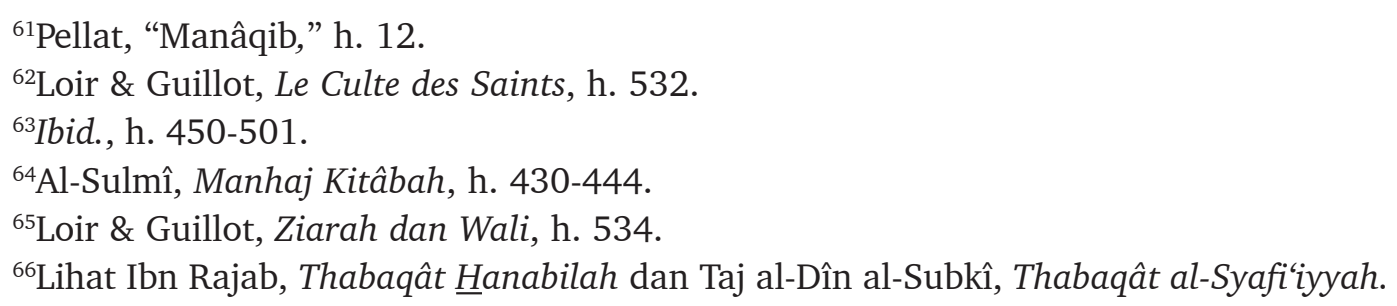


tradisi mazhab atau memiliki pengaruh yang sangat luar bisa dalam menumbuhkankembangkan komunalitas mazhab, baik fikih atau sufisme, maka yang seringkali muncul bukan hanya berada pada sekedar tulisan biografinya sebagaimana aktualisasi model pertama, tapi juga dalam edisi khusus ia dimunculkan. Mereka dilebihkan dengan aspekaspek penulisan keluarbiasaan, keramat, dan keunggulannya atau yang biasa disebut manâqibnya seperti halnya Manâqib Abû Hanifah, Manâqib Imâm Syâfiî̀, dan Manâqib Syaikh Abû al-ㅍasan al-Syadzilî. Umumnya bila seseorang sudah dituliskan manâqibnya, biasanya tokoh tersebut bisa dipastikan sebagai tokoh mazhab yang sangat penting baik dalam bidang fikih maupun dalam bidang tasawuf. ${ }^{67}$

Secara antropologis, tradisi penulisan jenis biografi ketokohan di dunia Muslim Klasik dan Abad Pertengahan, nampaknya tidak hanya memunculkan dan mendorong ke arah pembentukan model-model penulisan yang sangat variatif, tetapi juga masingmasing model memberikan kontribusi secara tersendiri untuk menampilkan kesan simbolik dalam mengaktualisasi jenjang kepangkatan keulamaan atau tingkat intelektualitas dan pengaruhnya dalam mengukuhkan sebuah mazhab yang mereka diciptakan. Semua pola ini, semakin mengukuhkan bahwa tradisi intelektualitas Muslim telah terbentuk secara permanen bukan hanya secara struktural tetapi juga berikut gerakan dan efek kultural yang dikembangkannya. ${ }^{68}$

Dari hirarki model-model tulisan ini bukan hanya bisa mengetahui sejauhmana peran ketokohan seseorang yang terbukti dengan banyaknya jumlah tulisan dalam menggambarkan keagungan tokoh yang ditampilkannya, tapi juga kapasitas karya yang mereka ciptakan (terutama oleh murid-murid seniornya), secara kultural akan terus-menerus membentuk pengaruh akademik bagi murid-murid junior yang berada di belakangnya. Kitab manâqib dalam dimensi psikilogis-akademis, nampaknya memang diciptakan untuk membangun rasa kebanggaan dan membangun komunitas mazhab yang berada di dalamnya. ${ }^{69}$ Dalam aspek-aspek tertentu, kitab manâqib ini berfungsi pula sebagai bentuk bendera sebuah mazhab, bahkan jika perlu seringkali bisa dimanfaatkan oleh para komunitasnya untuk menampilkan sesuatu yang bisa mempengaruhi komunitas lainnya. ${ }^{70}$

Ada kecenderungan, bahwa penulisan kitab manâqib tentang tokoh-tokoh sufi, pada umumnya ditulis oleh murid-murid tarekatnya, dan merka menunjukkan dirinya berasal dari lintas mazhab fikih. Namun sebaliknya para penulis kitab manâqib tokoh fikih, kebanyakan selalu berasal dari lingkungan mazhab tokoh yang ditulisnya. Berikut ini di antara juduljudul kitab manâqib berikut pengarangnya dari berbagai kalangan mazhab fikih dan tasawuf

${ }^{67 P e l l a t, ~ " M a n a ̂ q i b, " ~ h . ~ 12-13 . ~}$

${ }^{68}$ Loir \& Guillot, Ziarah dan Wali, h. 537.

${ }^{69}$ Muhamad Abû Zahrah, al-Târikh li al-Madzâhib al-Islâm (Surabaya: Kutub al-'Arabiyyah, 1984), h. 6-7.

${ }^{70}$ Loir \& Guillot, Ziarah dan Wali, h. 539. 


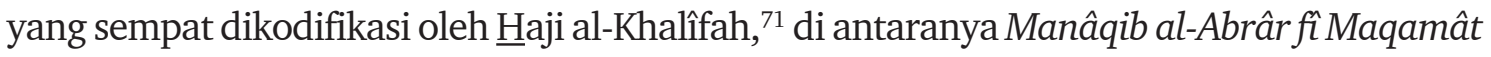
al-Akhyâr karya Muhammad bin Hasan al-Husainy al-Syâfîî (w. 767 H), al-Manâqib alIbrâhimiyah wa al-Ma'atsîr al-Khudaiwiyyah karya Iskandar Ibkarius al-Bairutî, Manâqib Ibn al-Furât karya Abî Bakr Muhammad bin Yahya al-Shulî (w. 335 H), Manâqib al-Imâm

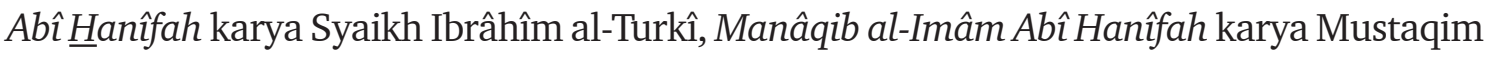
Zadah al-Rûmî, Manâqib al-Imâm Ah̆mad bin ㅂanbâl karya Abî al-Fadhl Muhammad bin Nashir bin Muhammad bin 'Alî bin 'Umar al-Salafî al-Fârisî al-Bagdâdî al-Hananbalî (w. 505 H), Manâqib al-Imâm al-Syâfiî karya Ibn Fahd al-Makkî Muhammad bin Muhammad Badr al-Dîn al-Hasyimî al-Syâfi'î (w. 826 H), Manâqib Amîr al-Sulthân wa Asrâr al-'Ârifinn karya 'Alî Zadah al-Rûmî, Manâqib al-Nûriyyah karya Jamal al-Dîn Abî al-Hasan 'Alî bin Ahmad bin Bisam al-Sya'ir (w. 303 H). ${ }^{72}$

Dengan melihat judul dan jumlah karya yang sangat variatif dengan tema umum manâqib, maka tingkat partisipasi dalam penulisan manâqib dari berbagai kalangan sosial dan intelektual Muslim sangat antusias dan menarik. ${ }^{73}$ Keberagaman model penulisan ini telah memberi dampak yang sangat kuat bagi munculnya sejumlah karya yang berkait dengan penulisan sejarah personal dalam historiografi Islam. Satu hal yang cukup menarik, sebagaimana dinyatakan di atas, bahwa secara kategoris penulisan kitab manâqib para tokoh sufi seringkali ditulis oleh lintas mazhab fikih misalnya manâqib Syaikh Abd alQadîr al-Jailânî telah ditulis oleh ulama-ulama baik dari kalangan mazhab fikih Hanafi, Maliki, Syâfi'î maupun dari kalangan Hanbalî sendiri. Mengingat mazhab tasawuf atau tarekat nampaknya cukup universal untuk diikuti oleh berbagai kalangan mazhab fikih. Sebaliknya, penulisan manâqib tokoh-tokoh fikih, pada umumnya hanya ditulis oleh penulispenulis yang berasal dari kalangan mazhab mereka sendiri, meskipun ada juga beberapa penulisnya yang berasal dari lintas mazhab. ${ }^{74}$

Namun yang jelas, semua penulisan manâqib tentang tokoh mazhab fikih, sebagaimana dinyatakan oleh Imam Abî Ja'far Muhammad al-Thahâwî (w. 321 H) adalah untuk memberi pengetahuan yang maksimal bagi para pengikut sebuah mazhab, karena ia akan mengenal lebih dekat tentang keunggulan kepribadian pendirinya, pemikirannya,

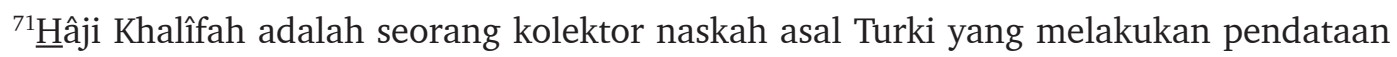
terhadap karya-karya penulis Muslim yang ia susun secara alfabetis berikut perumpunan berdasarkan pembidangan keilmuannya. Nama lengkap Hâji Khalîfah adalah al-Maula al-Musthafa bin 'Abd Allâh al-Qasthantî al-Rûmî al-Hanafî (w. 1657 M). Lihat karyanya yang sangat monumental Kasyf al-Dzunûn, Juz 1- 6. Untuk pendataan Kitab Manâqib lihat pada Juz II, h. 671-678 dan Juz IV, h. 374-375.

${ }^{72}$ Hâjji Khalîfah, Kasyfal-Dzunûn, Jilid IV, h. 376-377. Pendataan judul-judul kitab manâqib di atas menjelaskan secara faktual, eksistensi dan tradisi penulisan ketokohan dengan pola manâqib (hagiografi).

${ }^{73}$ Loir \& Guillot, Ziarah dan Wali, h. 356

${ }^{74}$ Manâqib al-Imâm Mâlik Radliyallah 'anhu oleh Abû al-Rûh Îsa bin Mas'ûd al-Syâfiî̀ (w. 774 H.) dan Tazyîn al-Arâik bi Manâqib al-Imam al-Mâlik oleh Jalâl al-Dîn al-Suyûthî. Lihat Hâji Khalîfah, Kasyf al-Dzunnun, Juz II, h. 675. 
Ajid Thohir: Bio-biografi dan Perkembangan Mazhab Fikih dan Tasawuf

situasi dan kondisi zamannya, murid-muridnya dan gagasan-gagasannya. ${ }^{75}$ Sedangkan fungsi manâqib di kalangan sufi adalah selain memperkuat kedudukan sebuah tarekat, tapi yang lebih konkrit adalah sebagai bahan pelajaran bagi para salik untuk menempuh perjalanan sufistik sebagaimana tokoh yang digambarkan lewat kitab manâqib tersebut. Dalam hal ini, kitab manâqib sekaligus sebagai media dalam kurikulum sufistik. ${ }^{76}$

\section{Penutup}

Pengaruh dari tradisi penulisan, dorongan doktrin, serta paradigma dan epistemologi intelektual Muslim terhadap kesadaran sejarah, jelas memberi akumulasi yang sangat kuat bagi perkembangan dalam historiografi Islam, khususnya penulisan sejarah tokoh. Lahirnya berbagai model penulisan sejarah tokoh, jelas bukan serba kebetulan, namun keberadaannya akibat akumulasi intelektual dan muatan kultural keagamaan yang sangat mendalam. Secara pragmatis, studi ketokohan, khususnya yang mengkristal dalam bentuk hagiografi (Kitâb al-Manâqib), secara langsung sebagai penyanjungan ketokohan baik oleh kalangan para pendukung mazhab fikih dan kelompok tarekat sufi maupun oleh para sejarawan Muslim dan ahli-ahli keislaman. Kehadiran kitab-kitab manâqib di kalangan ahli fikih dan tasawuf memiliki korelasi yang sangat kuat dan sangat signifikan dalam menentukan jalannya sebuah perkembangan mazhab fikih dan tarekat sufi. Kecenderungan ini muncul, terutama pada periode Abad Pertengahan sejarah Islam. Secara realistik, karyakarya tersebut juga secara tidak langsung telah memberi legitimasi secara psikologis terhadap pengikut mazhab dan memberi penguatan bagi para penulis-penulis muda berikutnya terutama untuk menunjukan kesetiaan dalam melakukan pendukungan atau kepengikutan pada sebuah mazhab fikih maupun tarekat sufi tertentu secara konkrit.

\section{Pustaka Acuan}

Abû Zahrah, Muhammad. al-Târikh li al-Madzâhib al-Islâm. Surabaya: Kutub al-'Arabiyyah. 1984.

Aron, Raymond. Introduction to the Philosophy of History. New York: Doubleday Anchor. 1961.

Abdullah, Taufik. "Sejarah dan Historiografi," dalam Ilmu Sejarah dan Historiografi: Arah dan Perspektif. Jakarta: Gramedia. 1985.

Chamber-Loir, Henri, \& Clude Guillot. Ziarah dan Wali di Dunia Islam. Jakarta: Serambi Ilmu Semesta. 2007.

Faruqi, Nisar Ahmed. Early Muslim Historiography. Delhi: Idarah-i Adabite Delli. 1979.

${ }^{75}$ Hâji Khalîfah, Kasyf al-Dzunûn, Jilid II, h. 672.

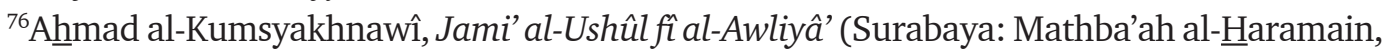
t.t.), h. 282. 
MIQOT Vol. XXXVI No. 2 Juli-Desember 2012

Al-Ganî, Yusri 'Abd. Mu’jam al-Muarrikhîn al-Muslimîn. Kairo: Dâr al-Turats. 1998.

Al-Husain, Hamid. Peristiwa Gaib, Barakat dan Mukjizat Kenabian Muhammad SAW. Bandung: Pustaka Hidayah. 2006.

Ibn Mandzur. Lisân al-Arab. Juz I. Beirut: Dâr Fikr. t.t.

'Îsâ, 'Abd al-Qadir. Haqâiq 'an al-Tashawwuf. Syiria: Dâr Ma'ârif Suriah Halab. 2001.

Kartodirdjo, Sartono. Pemikiran dan Perkembangan Historiografi Indonesia: Suatu Alternatif. Jakarta: Gramedia. 1982.

Kasyif, Sayyidah Ismâ‘îl. Mashâdir al-Târikh al-Islâmî wa Manâhij al-Bahts Fîqh. t.t.p.: Mathba'ah al-Sa'adah. 1976.

Khalafullâh, Muhammad, dalam al-Fann al-Qashshi fì al-Qur'ân al-Karîm. Kairo: alNahdlah al-Mishriyyah. 1957.

Khalîfah, Hâji. Kasyfal-Dzunûn 'an Asamy al-Kutub wa al-Funûn. Jilid II. Beirut: Dâr Fikr. 1993.

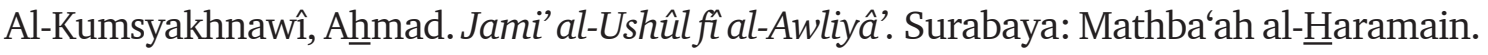
t.t.

Al-Kâfiyaji, Al-Muhy. "al-Mukhtashar fî 'Ilm al-Târikh," dalam 'Izz al-Dîn 'Alî. Dirâsât alNaqdiyyat fî al-Mashâdir al-Tâikhiyyat. Beirut: 'Alam al-Kutub. t.t.

Morris, William, et al. (ed.). The Heritage Illustrated Dictionary of the English Language. Vol. I. Boston: Houghton Mifflin Company. 1979.

Murray, James A. H., et al,. ed.). The Oxford English Dictionary. Oxford: The Clarendon Press. 1978.

Al-Maula, Muhammad Jad, et al. Qashash al-Qur'ân. Beirut: Dâr al-Jail. 1988.

Al-Nabhanî, Yûsuf. Jâmi’ al-Karâmah. Juz I. Beirut: Dâr Fikr. 1989.

Nashshar, Hussain. Nasy'at al-Tadwîn al-Târikhy inda al-Arab. Kairo: Maktabah al-Mishriyah. t.t.

Al-Nawâwî. Shahîh $\underline{h}$ Muslim bi Syarh Imâm al-Nawâwî. Juz IV. Bandung: Maktabah Dahlan Bandung. t.t.

Pellat, Ch. "Manâqib," dalam the Encyclopaedia of Islam. Leiden: Koninklijke Brill. NV, t.t.

Rosenthal, F. A History of Muslim Historiography. Leiden: E. J. Brill. 1968.

Rosenthal, F. "Islamic Historiography," dalam David L. Sills (ed.). International Encyclopedia of Social Sciences, Vol. V. New York: The Macmillan Company \& the Free Press. 1972.

Al-Râzî, Muhammad bin Abû Bakar bin 'Abd al-Qadîr. Mukhtâr al-Shihhah. Beirut: Dâr Fikr. t.t.

Sâlim, Sayyid 'Abd al-Azîz. al-Târikh wa al-Muarrikhûn. Beirut: Dâr al-Nahdhah alArabiyyah. t.t.

Al-Sakhawî, Syams al-Dîn. "Al-I'lân bi al-Taubîkh li man Dzamma Ahl al-Târikh." dalam Muhammad Kamâl al-Dîn 'Izz al-Dîn 'Alî. Dirâsât al-Naqdiyyat. t.t.: t.p., t.t. 
Al-Suyuthî, Jalâl al-Dîn. Jâmi’ al- Shâghir, Juz VII. Beirut: Dâr al-Khair, t.t.

Al-Sya'râwî. Qashas al-Anbiyâ'. Beirut: Dâr 'Ilmiyyah. 2009.

Al-Tirmizî, al-Hafiz Abî ‘̂̂sâ Muhammad. Kitâb Jâmi' al-Shahîh $\underline{h}$. ditahqiq 'Abd al-Wahhab bin 'Abd al-Lathif. Semarang: Maktabah Thoha Putra. 1967.

Al-Thûsî, Sirâj al-Dîn. Kitâb al-Luma‘. Beirut: Dâr Kutub al-'Ilmiyah. 2001.

Umar, A. Muin. Historiografi Islam. Jakarta: Rajawali Press. 1988.

Walsh, W. H. Philosophy of History: An Introduction. New York: Harper Torchbooks. 1967. Yatim, Badri. Historiografi Islam. Jakarta: RajaGrafindo, 2003. 